\title{
Cervical Ganglia
}

National Cancer Institute

\section{Source}

National Cancer Institute. Cervical Ganglia. NCI Thesaurus. Code C98713.

Any one of the three sympathetic ganglia of the cervical vertebrae. 